\title{
Az állami tanítóképzés történetének fordulópontjai
}

\section{Kelemen Elemér}

Eötvös Loránd Tudományegyetem, Tanító- és Óvóképző Kar, ny. főigazgató

\begin{abstract}
A 2019-es esztendő három jeles évfordulót is kínál számunkra a magyar tanitóképzés történetéből: 150 éve, 1869-ben jöttek létre Eötvös 1868-as népiskolai törvénye alapján az első - középfokú - állami tanitó/nőképezdék. 60 éve, 1959-ben alakultak meg a képzés szintemelését jelentő, akadémiai jellegü - fél-felsőfokú - tanitóképző intézetek és 25 éve, 1994-ben került elfogadásra az a képesitési követelményrendszer, amely szakmai alapját jelentette a négyéves időtartamú föiskolai tanitóképzésnek és utat nyitott a képzés 21. századi perspektívákat kináló továbbfejlesztéséhez. Az elóadás szerkesztett változata az „állami” tanitóképzés hazai történeti változásait, fejlődési ivét mutatja be e három nagy korszak (fordulópont) eseményei köré rendezve.
\end{abstract}

Kulcsszavak: állami tanitóképzés, törvényi szabályozás, tanitóképzés korszakai

DOI: 10.37205/TEL-hun.2019.ksz.01

\section{Bevezetés}

A 2019-es esztendő a véletlenek összejátszása folytán három jeles évfordulót is kínál számunkra a magyar tanítóképzés történetéből:

- 150 éve, 1869-ben jöttek létre Eötvös 1868-as népiskolai törvénye alapján az első - középfokú - állami tanító/nőképezdék;

- 60 éve, 1959-ben alakultak meg a képzés szintemelését jelentő, akadémiai jellegü - fél-felsőfokú - tanítóképző intézetek és

- 25 éve, 1994-ben került elfogadásra az a képesítési követelményrendszer, amely szakmai alapját jelentette a négyéves időtartamú főiskolai tanítóképzésnek és utat nyitott a képzés 21. századi perspektívákat kínáló továbbfejlesztéséhez.

Mindhárom esemény önmagában is alkalom lehetne az ünnepi megemlékezésre. Így együtt azonban szimbolikus jelentést hordoznak: a magyar tanítóképzés történeti változásainak, fejlődési ívének hármas pillérét, az előadás címében is jelzett „fordulópontjait” jelentik.

Ez, az intézményi jelleg változásaiban kifejlődő, immanensnek tűnő fejlődési tendencia látszólag független utolsó másfél évszázadunk történelmi-társadalmi és 
politikai - változásaitól. Az események hátterében azonban kirajzolódik a 19-20. századi magyarországi modernizáció ellentmondásokban - útkeresésekben és úttévesztésekben - gazdag története, ami hol ösztönözte, hol hátráltatta tanítóképzésünk - bizonyos mértékig öntörvényűnek tekinthető - változásait.

Itt jegyzem meg, hogy az állami tanítóképzés eredetileg alternatívaként, mintegy a felekezeti képzések versenytársaként jelent meg a történetben. Az állami dominanciára való törekvés, majd az állami monopolhelyzet kialakulása - kezdetben a nemzetállami fejlődés függvényeként, majd a szovjet típusú politikai berendezkedés következtében - későbbi korok fejleménye. Ennek a folyamatnak sajnálatos velejárója az alternatívák burkolt, majd nyílt felszámolása, a képzésnek - az oktatási rendszer egészére jellemző - központosítása és homogenizálódása, ami a későbbiekben feleslegessé teszi az előadás címében is olvasható „állami” jelző megkülönböztető használatát.

A magyar tanítóképzés fejlődéstörténete szerves része és meghatározó eleme az oktatásügyi modernizáció hazai történetének. A modern oktatási rendszerek 18. századig visszavezethető kialakulásának és fejlődésének ugyanis - az iskoláztatás expanziója, a különböző gyökerű és típusú intézmények összehangolódása, rendszerré szerveződése, valamint a növekvő állami szerepvállalás, az erősödő politikai befolyás mellett - jellemző vonása a neveléssel-oktatással hivatásszerűen foglalkozó szakmai csoportok kialakulása és elkülönülése, a különböző képzési formák és az alkalmazási feltételt is jelentő képesítési követelmények megjelenése, valamint a szakmai-tudományos háttér és a szakmai-egzisztenciális érdekképviselet létrejötte, azaz a pedagógusmesterség szakmává válása, professzionalizációja (Halász, 2001).

\section{A középfokú képzés időszaka (1869-1958)}

A dualista korszaknak a magyar iskolarendszer szerkezetét és fejlesztési irányát meghatározó, alapvető oktatási törvényei - a népiskolai oktatásról szóló 1868. évi XXXVIII. tc., a középiskolákról rendelkező 1883. évi XXX. tc., valamint a kisdedóvást szabályozó 1891. évi XV. tc. - az egyes intézménytípusok társadalmi funkciójának, oktatáspolitikai céljának, szervezeti és működési feltételeinek körültekintő szabályozása mellett - nagy figyelmet fordítottak a „tanszemélyzet” képzésének iskolaszervezeti és tartalmi kérdéseire, a képesítési követelmények, illetve az alkalmazási feltételek szabatos meghatározására (Köte, 1975; Felkai, 1979; Mann, 1993; Kelemen, 1994, 1997, 2001, Nagy, 1997, 2002). Megjegyzendő, hogy a közok- 
tatási intézmények eltérő genezise, a modern tömegoktatást szolgáló népiskola és az elitoktatás hagyományait őrző középiskola társadalmi funkciójában és pedagógiai filozófiájában kimutatható, napjainkig - fellelhető különbségek rányomták bélyegüket az egyes iskolafokozatokhoz igazodó, hierarchizálódó pedagógusképzésre, ami nemcsak a képzés eltérő szintjében, hanem szemléletmódjában, tartalmi-módszertani irányultságában is tükröződött, és kihatott az egyes pedagóguscsoportok társadalmi helyzetére, anyagi-erkölcsi megbecsülésére is (Kelemen, 2007).

Az 1868. évi népoktatási törvénynek a tanítósággal kapcsolatos rendelkezései sajátos szintézisét jelentették a korábbi, csaknem évszázados előzményekre viszszatekintő állami (lásd: Ratio Educationis) és a különböző felekezeti indíttatású katolikus, protestáns és izraelita - rendezési, szabályozási törekvéseknek, ha úgy tetszik: a nemzeti hagyományoknak, valamint a széles körből, elsősorban a német, az osztrák és a svájci népoktatási és tanítóképzési gyakorlatot körültekintően megszervezett feltérképezéséből származó nemzetközi tapasztalatoknak.

A törvény egyik lényeges alapvonása, hogy szerves egységként fogta fel a népiskolai oktatást és a népiskolai tanítók képzését. Az általa előírt szakképesítést nyújtó háromévfolyamos tanító/nőképezdéket a népoktatási intézmények közé, a népiskolai törvény hatálya alá sorolta. Ez a döntés mintegy determinálta a tanítóképzésnek a hazai közoktatás fejlesztésében betöltött mindenkori, napjainkban is érvényes küldetését.

A törvény a kor színvonalán és a realitásokhoz, így a tízezresre becsült tanítóhiány sürgető kényszeréhez és az adott anyagi és szellemi feltételekhez igazodóan kereste a megoldást, így - a tanszabadság és a tanítás szabadsága jegyében - deklarálta az intézménylétesítés és -fenntartás pluralizmusát, megerősítette a felekezetek ezirányú jogait. Ennek mértékét mutatja, hogy 1867-ben 43 felekezeti tanító/nőképző működött Magyarországon (Sebestyén, 1896; Szakál, 1934; Kelemen, 1993).

A tankötelezettség bevezetésével együtt járó, súlyos tanítóhiány enyhítése érdekében azonban - az állam ezirányú felelősségét hangsúlyozva - a törvény 20 állami tanítóképző felállítását rendelte el. Részletesen szabályozta - lásd: 81-115. szakasz - ezek létesítésének és működésének feltételeit, így - többek között - a gyakorló iskola és a tankert (gyakorló kert) szükségességét, a tanári személyzet minimumát, a felvétel kritériumait, a képzés hároméves időtartamát és kötelező tantárgyait, az épületre és a köztartásra vonatkozó előírásokat, az igazgató tevé- 
kenységét, az igazgatótanács összetételét és feladatait, valamint az évi nyilvános vizsgák és a záróvizsgák rendjét. A 105. szakasz ugyanakkor nem zárta ki - megfelelő feltételek esetén - magánképezdék létesítését sem.

A (hit)felekezeti tanítóképzők létesítéséét és működését a törvény 13. szakasza szabályozta. A kötelező kritériumok között a gyakorlóiskola megléte, a tananyagnak az állami képzéssel való egyezése, az évenkénti nyilvános vizsgák és a záró „szigorlatok” megszervezése szerepelt.

Az 1869-ben létesített első állami képezdéket csakhamar továbbiak követték; számuk az 1870-es évek végén már 23 volt. A szigorúbb törvényi előírások - így például a háromévfolyamos képzés bevezetése a korábbi kétévfolyamossal szemben - azonban megrostálták a felekezeti képzőket, számuk egy évtized alatt csaknem egyharmadával csökkent.

A korszak végén (1918) összesen 91 tanító/nőképző működött Magyarországon: 50 állami és 41 felekezeti (56-44 százalékos arány). Az intenzív fejlesztés eredményeképpen a néptanítók száma csaknem megduplázódott (1868: 17992, 1910: 32402 fö), és jelentősen csökkent - a tankötelezettség fokozatos kiteljesedése mellett - az egy tanítóra jutó népiskolai tanulók száma (1869-ben átlag 90,78, 1910-ben 73,66 hat-tizenkét éves tanköteles) (Kelemen, 2007).

$\mathrm{Az}$ állami és a felekezeti tanítóképzők fentebb említett arányától ugyanakkor feltűnően eltér a népiskolák vonatkozásában regisztrálható 73,5-25 százalékos arány (1910). Ennek az aszimmetriának nyilvánvaló magyarázata a dualista korszak nemzetiségi és iskolapolitikájának az eötvösi elvektől és törvényektől (népoktatási és nemzetiségi törvény) fokozatosan eltérő - az 1890-es évektől felerősödő és a 20. század első évtizedeiben kiteljesedő - magyarosítás szándéka, ami elsősorban a felekezeti fenntartású nemzetiségi népiskolák működésének államigazgatási és financiális eszközökkel, nem utolsó sorban a személyzeti politika által történő befolyásolására, korlátozására irányult. Az állami tanítóképzőkben mindinkább eluralkodó nacionalista szellemben képzett tanítók a nemzetiségek lakta területek népiskoláiban ennek a politikának voltak az előőrsei (Halász, 1902; Dolmányos, 1968; Kelemen, 1994; Nagy, 1997, 2002).

A Vallás- és Közoktatásügyi Minisztérium, személy szerint Gönczy Pál államtitkár és közvetlen munkatársai oktatásfejlesztési szempontból is fontos szerepet szántak az állami tanítóképzésnek, kiemelten a „mintaképezdeként” elgondolt budai intézménynek. Egyrészt az új típusú tanítóképzés szervezeti kereteinek, müködési rendszerének, tantervi tartalmának modellértékű, mintául szolgáló kidol- 
gozását és folyamatos fejlesztését, másrészt a népoktatás megújításában való aktív közreműködésüket várták el.

Ez utóbbi tevékenység meggyőző példája a képzőintézeti tanárok részvétele az elemi és a felsőbb népiskolai, valamit a polgári iskolai tantervek, tan- és vezérkönyvek kidolgozásában; kiterjedt a publikációs tevékenységük mindenek előtt a Néptanítók Lapjában és más országos és helyi orgánumokban, később a Magyar Tanítóképzőben, továbbá intenzív a közremúködésük a tanító-átképző és továbbképző tanfolyamok rendezésében és lebonyolításában. Ez a szerep - tudatosan vállalt örökségképpen - végig kísérte a magyar tanítóképzés történetét. A példákat Bárány Ignáctól és Gyertyánffy Istvántól Quint Józsefig és Drozdy Gyuláig vagy akár napjainkig terjedően hosszan lehetne sorolni.

Nem kisebb jelentőségű az új rendszerű tanítóképzés megteremtésében és folyamatos fejlesztésében vállalt szerepük: a folyamatosan bővülő képzési tartalom és a korlátozó szervezeti keretek összehangolása, a képzés időtartamának kiterjesztése; a tantervek korszerűsítése, tankönyvek, módszertani útmutatók kidolgozása; a polgári iskolai és képzőintézeti tanítóképzés megalapozása és megszervezése. Túlzás nélkül állíthatjuk, hogy a budai képző köré szerveződő Paedagogium - Gyertyánffy István vezetésével - fénykorában a magyar népoktatás és a tanítóképzés hiánypótló tudományos és kísérleti mühelyeként funkcionált.

De az ismertebb budai példák mellett felemlíthetem a végeken működő és a létéért állandó küzdelmet folytató Csurgói Állami Tanitóképző tevékenységét, amelynek tanárai - az intézményalapító Bárány Ignác, a kadarkúti néptanítóból tanárrá lett Horváth fózsef, a korai gyermektanulmányozás úttörői között számon tartott Pethes fános vagy az országos szerepeket is vállaló Mohar fózsef-motorjai voltak az évtizedeken át eredményesen múködő Somogy megyei és a Csurgói járási Tanítóegyletnek, a megyei tanfelügyelőséggel karöltve hét évtizeden át megyei oktatásügyi szaklapot adtak ki, a Népiskolai (később Iskolai) Szemlét; publikációs tevékenységük túlnőtt a megyehatárokon, gyakran találkozhatunk nevükkel országos szervezetekben, orgánumokban is.

Az egyes intézményekben folyó - és a felekezeti tanítóképzők számára is mintául szolgáló - mủhelymunkát emelte országos szintre a tanítóképző intézeti tanárok szakmai szervezetének a megalakulása (TITOE, 1886) és az egyesület rangos és népszerủ folyóirata, a Nagy László által szerkesztett Magyar Tanitóképző (1886), amely évtizedeken át szakmai fórumot és iránymutatást jelentett - felekezeti különbségek nélkül - a magyar tanítóképzés szakemberei számára. 
A századfordulóhoz közeledve megélénkültek a tanítóképzés továbbfejlesztését szorgalmazó viták, amelyek során többféle elképzelés is hangot kapott, meghatározva a következő évtizedek - sajnos meddőnek bizonyuló - szakmai és (oktatás)politikai diszkusszióinak tárgyát. Így került napirendre a középfokú képzés öt vagy hat évfolyamosra bővítése, a négyéves, speciális tartalmú és érettségivel záruló középfokú képzésre épülő kétéves - akadémiai jellegü - képzés, illetve a középiskolai érettségire alapozott, esetleg egyetemhez is kapcsolódó felsőfokú, főiskolai képzés koncepciója. A döntést - mint a későbbiekben oly sokszor - a szakmai és politikai megosztottság és ellenérdekeltség késleltette, majd az első világháború kitörése odázta el.

A következő évtizedekben, annak ellenére, hogy az egymást váltó politikai korszakok - taktikai megfontolásból, a tanítóság megnyerése érdekében - egyaránt kilátásba helyezték a tanítóképzés régóta esedékes reformját, nem történt érdemi változás, és - az 1938-as, lényegében sikertelen próbálkozástól eltekintve - 1959-ig fennmaradt a váltakozó évfolyamú, öt-, majd ismét négyévfolyamos középfokú képzés.

Az 1918/19-es forradalmakat követő ellenforradalmi rendszer iskolapolitikája 1920-ban a hat, 1923-ban - a realitásokhoz, elsősorban a fegyelmi és büntető eljárások következtében elóállt súlyos tanítóhiányhoz igazodva - az ötéves középfokú képzés mellett döntött. A népoktatás színvonalemelését szolgáló, presztízsnövelő intézkedések és gesztusok - Klebelsberg népiskolaépítési programja, a nyolcévfolyamos népiskola koncepciójának meghirdetése, a '20-as évek második felében végrehajtott tanítói béremelés, majd a tanítóság nemzetpolitikai szerepét hangsúlyozó gömbösi retorika - sorába tartozott és a tanítóságnak tett korábbi ígéretek beváltását helyezte kilátásba a tanítóképzés 1938-as reformja. Ennek lényege egy speciális irányultságú középiskolára, az érettségivel záruló líceumi képzésre épülő, kétéves akadémiai - azaz fél-felsőfokú - képzés törvénybe iktatása volt (1938. évi XXVI. tc.). A program megvalósulását azonban a körülmények alakulása - a terület-visszacsatolásokkal, majd a második világháborúval együtt járó súlyos tanítóhiány - megakadályozta, a törvényt végül hatályon kívül helyezték. Megjegyzendő, hogy az 1930-as évek centralizáló oktatáspolitikájának szellemében felerősödött a nem állami fenntartású intézmények indirekt módon - az állami támogatásokhoz kapcsolódó elvárások érvényesítésével történő - burkolt államosítása, ami - egyebek mellett - a tanítóképzés egységes nemzeti arculatának kialakítását és megerősítését célozta. Ezek az intézkedések - paradox módon - 
mintául szolgáltak a tanítóképzés világnézeti-politikai tartalmának későbbi, központi vezérléssel történő szabályozásához.

1945 után az általános iskola rendeleti úton megvalósult, a társadalmi, politikai és szakmai konszenzust egyaránt nélkülöző és feltételek nélküli „bevezetése” jelentett új kihívást a tanítóképzés számára is. A nyolc évfolyamra képesített „általános iskolai tanítókat" képező pedagógiai főiskola koncepciója és budapesti megvalósítása kudarcos kísérletnek bizonyult. Néhány év zavaros viszonyait követően, miközben az 1948-ban megszüntetett tanítóképzők utódaként - 1949-ben „pedagógiai gimnáziumok” létesültek, némi korrekcióval visszaállt a régi rend. 1950-től a négy évfolyamosra redukált és gyakorló évvel megtoldott középfokú képzés keretében folytatódott az általános iskola alsó tagozatára képesített tanítók képzése. A felkészítés elsődleges feladata ezekben, az ún. „ötvenes” években a klerikális befolyás elleni harc és a politikai-világnézeti nevelés hatékonyságának a „fokozása” volt.

A magyar oktatásügy történetének drámai fordulópontját jelentette a nevelési-oktatási intézmények és tanszemélyzetük állami kezelésbe vételéről szóló 1948. évi XXXIII. törvény, amely - a szekularizáció bolsevik típusú végrehajtásával - megszüntette az intézmény-létesítés és -fenntartás pluralizmusát és felszámolta a felekezeti tanítóképzést is. A törvény értelmében 47 egyházi tanítóképző - köztük 31 római katolikus és 8 református - került államosításra (Kelemen, 2007).

\section{„Nem középiskolás fokon”. A hároméves felsőfokú, majd főiskolai tanítóképzés időszaka (1959-1995)}

A Magyar Népköztársaság Elnöki Tanácsának 1958. évi 26. sz. törvényerejü rendelete - többéves meddő vitákat és politikai-taktikai alkudozásokat követően - megszüntette a középfokú képzést és a középiskolai érettségire alapozott, háromévfolyamos tanítóképző intézetek létesítését rendelte el.

A képzési rendszer évek óta tervezett átalakítása a forradalmat követő konszolidáció időszakában elsődlegesen politikai indíttatású döntés, amelynek hangsúlyozott célja az iskolai nevelő-oktató munka szocialista jellegű erősítése és - ennek érdekében - a tanítóság világnézeti-politikai nevelésének hatékonyabbá tétele volt.

Az újonnan létrehozott intézmények - szám szerint tíz (Baja, Budapest, Debrecen, Esztergom, Győr, Jászberény, Kaposvár, Nyíregyháza, Sárospatak, Szombat- 
hely) - nagy erőfeszítések árán birkóztak meg a felsőfokú képzés előzmény- és hagyománynélküliségéből eredő szervezési és tartalmi problémákkal, így például az 1959-es központi tanterveknek az ideológiai-politikai képzést előtérbe állító egyoldalúságával vagy a szakmai és a politikai elvárásoknak egyaránt megfelelő oktatói személyzet kialakításával. Évekbe telt, amíg kialakult a szaktudományi és a szakmai ismeretanyag optimálisnak tűnő aránya, a pedagógiai-pszichológiai tantárgyak és a szakmódszertanok „emelt szintű” tartama, valamint a gyakorlati képzés rendje. Az új tantárgyi programok és a hozzájuk kapcsolódó tankönyvek, jegyzetek kidolgozása a tanítóképzés tanárainak elismerésre méltó kollektív teljesítménye volt, a későbbi továbblépés tapasztalatokban gazdag előiskoláját jelentette.

Növelte a nehézségeket a permanens tanítóhiány enyhítését szolgáló esti és levelező képzés kényszerű kapacitásbővítése, ami súlyos terhet jelentett az identitásukat kereső tanintézetek számára, különösen a gyakorlati képzés vonatkozásában.

Az 1960-as évek - a fentebb vázolt problémák ellenére - a közoktatással és a tanítóképzéssel összefüggő tudományos tevékenység megújulását és kiteljesedését is magukkal hozták. Az igényes önfejlesztő munka kézzelfogható eredményei - új tantárgyi programok, tankönyvek, a gyakorlati képzés megújítása, képzésfejlesztési koncepciók és javaslatok stb. - érdemben hozzájárultak a tanítóképzés 1974/75-ben bekövetkezett, a korábbinál szakmai szempontból kétségtelenül megalapozottabb továbbfejlesztéséhez, „feljebb sorolásához”: a változatlanul három évfolyamos, de már „főiskolaivá” nyilvánított képzés bevezetéséhez. Az 1974. évi 13. sz. törvényerejü rendelet alapján 1975 őszén nyolc tanítóképző főiskola és két kihelyezett tagozat kezdte meg működését (Baja, Budapest, Debrecen, Esztergom, Győr, Jászberény, Kaposvár, Sárospatak, illetve Zsámbék és Szekszárd).

Az ezt követő időszak - a képzés profilbővítéséből és az általános iskolai szaktanárhiány megoldását célzó, sokat vitatott szakkollégiumi rendszer bevezetéséből eredő átmeneti identitászavarok ellenére a magyar tanítóképzés történetének a száz évvel korábbiakhoz hasonlítható, hősies időszaka volt, amelyben - a permanens feltételhiány, a magas hallgatói létszám és az ezekből eredő működési nehézségek ellenére megteremtődtek a valóban főiskolai igényủ és színvonalú képzés tartalmi és személyi előfeltételei.

Az 1985. évi oktatási törvény az intézmények szakmai önállóságának és az oktatói szuverenitásnak a kinyilvánításával új helyzetet teremtett. A korábbi központi 
tanterveket felváltó tantervi irányelvek alapján megszülető helyi tantervekben és tantárgyi programokban megerősödött az osztálytanítói feladatokat középpontba állító, az eötvösi hagyományokból merítő klasszikus tanítóképzős szemlélet, összhangban az 1980-as éveknek az általános iskolai oktatás kezdő szakaszát előtérbe állító közoktatásfejlesztési törekvéseivel.

Az 1980-as évek útkereső próbálkozásaival, az ún. „modellkísérletekkel” egyidőben - amelyek több irányban is nyitottak voltak az óvó- és tanárképzéssel, valamint a gyógypedagógiai neveléssel kerestek kapcsolódási pontokat és együttműködési lehetőségeket - indult el a Budapesti Tanitóképtő Főiskolán - Hunyady Györgyné és Bollókné Panyik Ilona kezdeményezésére és szakmai irányításával, 14 tanítóképző főiskola szakembereinek aktív közremúködésével - a négyévesre bővülő főiskolai tanítóképzés koncepciójának kidolgozása és kísérleti kipróbálása, amely előkészítette és megalapozta a hazai tanítóképzés történetének harmadik, 1994/95-ös fordulatát (Kelemen, 2007).

\section{A négyéves főiskolai tanítóképzés időszaka (1995-)}

A rendszerváltozás utat nyitott azoknak a törekvéseknek, amelyek a magyar oktatásügyet az európai viszonyok közé kívánták visszavezetni. Az oktatás állami monopóliumának felszámolásával (lásd: az 1985. évi oktatási törvény módosítását jelentő 1990. évi XXXIII. törvényt) átalakult a magyar felsőoktatás fenntartói összetétele, lehetőség nyílott a tanítóképzés területén is egyházi létesítésű és fenntartású intézménynek meg-, illetve újjászervezésére (Nagykőrös, Esztergom, Zsámbék, Debrecen).

Az 1993-as felsőoktatási törvény (1993. évi LXXX. törvény) fordulatot hozott a magyar felsőoktatási intézmények tartalmi tevékenységének szabályozásában. A korábbi időszakok szigorúbb vagy lazább központi elöírásaiban (állami tantervek, tantervi irányelvek) megtestesülő bemeneti szabályozást a kimeneti szabályozás elvén alapuló új dokumentumok, a képesítési követelmények váltották fel. A pedagógusképzés szakterületei közül elsőként az óvodapedagógus és a tanító szak képesítési követelményei kerültek kidolgozásra, illetve kiadásra - [158/1994. (XI. 17.) Korm. rendelet] (Bollókné \& Hunyady Györgyné, 2003, Kelemen, 2012).

Az új követelményekhez igazodóan a főiskolai tanítóképzés időtartama a korábbi háromról négy évre emelkedett. A tágabb időkeret lehetővé tette a tanítói szakképesítés kibővítését a 6-10 éves gyermekek oktatásán-nevelésén túl egy választott „műveltségi terület” 5-6. osztályos tanítására is (Bollókné \& Hunyady 
Györgyné, 1995). A tanítói kompetencia ilyetén kiterjesztése évszázados hazai hagyományokra, a hatosztályos elemi népiskolára emlékeztetett, ugyanakkor igazodott az oktatás-fejlesztés nemzetközi tendenciáihoz és összhangban volt az iskolai alapozó szakasz tervezett hazai kibővítésével, a Nemzeti Alaptanterv eredeti koncepciójával.

Az 1994-ben elfogadott képesítési követelmények erősítették a tanítóképzés hagyományosan integratív jellegét, illetve az iskolai kezdő szakasz komplex - nevelő-képző és személyiségfejlesztő - funkcióját. A megnövelt képzési idő lehetőséget teremtett a gyakorlati képzés időtartamának bővítésére, tartalmi gazdagítására és a tanítói személyiség megalapozottabb fejlesztésére is (Kelemen, 2007, 2012).

A képesítési követelmények szerint kidolgozásra kerülő helyi tantervek és tantárgyi programok megfelelő színvonaláról és egyenértékűségéről a főiskolák képviselőiből álló Országos Tantervfejlesztő Bizottság (OTFB; alakult 1987-ben) és szakbizottságai mintatantervvel és programajánlatokkal gondoskodtak, elősegítve ezzel az intézményi tantervek zökkenőmentes bevezetését és a négyéves főiskolai képzés teljes körủ, egységes elindítását az 1995/96-os tanévben. Az új tantervek kontrollját és minősítését, ami egyben a szükséges korrekciók és a folyamatos fejlesztés előfeltétele is, az intézményi minőségellenőrzés kiépülő rendszere, az OTFB - 2004-től az Országos Programfejlesztő Bizottság (OPB) - szakmai felelősségvállalása, valamint a Magyar Akkreditációs Bizottság által lefolytatott akkreditációs eljárások együttesen biztosították, biztosítják (Podráczky, 2012; Kelemen, 2012).

Az átalakuló magyar tanítóképzésnek - a felsőoktatás egészéhez hasonlóan az ezredfordulón, három nagy kihívással kellett szembenéznie: a felsőoktatás szerkezeti átalakulását eredményező integrációval, a kreditrendszer bevezetésével, valamint a képzésfejlesztésnek is új perspektívákat kínáló, többszintű bolognai képzési szerkezetre történő átállással.

A felsőoktatási intézmények hálózat-átalakításáról szóló 1999. évi LII. törvény alapján 2000. január 1-től új felsőoktatási intézmények jöttek létre, számuk 89-ről 62-re csökkent (30 állami, 26 egyházi és 6 alapítványi, illetve magánintézmény). Az integráció eredményeképpen - különböző szervezeti megoldások keretében (többnyire egyetemi vagy főiskolai karként, részben önállóan) - 17 helyen folyt tanítóképzés. Az első tapasztalatok az integrációs folyamat bizonyos kockázataira is felhívták a figyelmet: a dezintegráció veszélyeire, a tanítóképzés szakmai-fej- 
lesztési szempontjainak a háttérbe szorulására, esetleges negligálására. A tanítóképző intézmények tartalmi együttmüködésének és a közös fellépésnek történetileg kialakult munkaformáit és szervezeti kereteit (Óvó-és Tanítóképző Egyesülete, főigazgatói kollégium, OTFB) gyengíteni látszott az eltérő profilú, sajátos hagyományú nagy intézményekbe történt, nem minden esetben önkéntes betagolódás (Kelemen, 2007).

A szakterület belső egyensúlyának, összetartó erejének megőrzése, újjászervezése az új körülmények között nem csupán tanítóképzős belügy, a pedagógusképzés és a közoktatás fejlesztésének egyik kulcskérdése is volt. A probléma kezelésére megnyugtató megoldást kínált a korábbi Országos Tantervfejlesztő Bizottság - átmeneti szünetet követő 2004-es újjászervezése (lásd: Országos Programfejlesztő Bizottság), valamint a tanítóképzést folytató intézmények eredményes szakmai együttmüködése - az ún. HEFOP-pályázatok keretében - a kreditrendszerre és a bolognai szisztémára történő áttérés egységes kezelésében (Podráczky, 2012).

Az integráció ugyanakkor új lehetőségeket is tartogatott számunkra: a képzésfejlesztés új perspektíváit, a tudományos továbbképzésekben és a kutatásokban való részvételt és együttműködést, a nemzetközi kapcsolatok bővülését. Igaz ez akkor is, ha a pedagógusképzés egésze - speciális igényeivel, finanszírozási gondjaival - a magyar felsőoktatás mostohagyermekének, hátrányos helyzetű területének számít.

Az ezredforduló másik nagy kihívását - és próbatételét - az európai normákhoz igazodó kreditrendszer kimunkálása és bevezetése jelentette [lásd: a 90/1998. (V. 8.) és a 200/2000. (XI. 29.) sz. kormányrendelet]. Az új rendszer megoldást ígért az itthoni és a nemzetközi (európai) megfelelés és egyenértékűség, az átjárhatóság és a hallgatói mobilitás megoldandó kérdéseire, ugyanakkor felgyorsította a pedagógusképzés szakterületeinek tartalmi és szervezeti közeledését is.

A szabályozás esetlegességei és következetlenségei ellenére - némi késéssel 2002-ben megszületett a tanítói szakcsoport sajátos képzési követelményeit a kreditrendszerű képzéshez illesztő kormányrendelet [77/2002. (IV. 13.) sz., illetve a 167/2003. (X. 21.) sz. módosítás] amely a főiskolai szintű tanítói szakra a nyolc féléves képzésnek megfelelően az összegyüjtendő kreditek számát 240 kreditpontban határozta meg.

A rendelet értelmezéséhez, a végrehajtás részleteinek a helyi tantervekben és tantárgyi programokban megvalósuló kidolgozásához a fentebb már említett HE- 
FOP-pályázatok keretében folyó, a képzőintézmények összefogásán alapuló, önfejlesztő tevékenység nyújtott megbízható szakmai hátteret.

A harmadik kihívást a magyar felsőoktatás igazodási, alkalmazkodási kényszerét jelentő bolognai folyamat jelentette, amely a kontinentális hagyományokat megtestesítő duális képzési rendszer helyett az angolszász gyakorlatban elterjedt lineáris, többlépcsős szerkezetet favorizálja.

A kormány - hosszantartó és a konszenzust számos ponton nélkülöző szakmai viták lezárásaként - 2004 nyarán adta ki „a többciklusú, lineáris felsőoktatási képzési szerkezet bevezetésének egyes szabályairól és az első képzési ciklus indításának feltételeiről szóló 252/2004. (VIII. 30.) sz. kormányrendeletet.

A rendelet szerint az első ciklust jelentő alapképzésben megszervezett alapfokozat végzettséget tanúsít, ami a munkaerő-piacon történő elhelyezkedéshez szükséges szakképzettséget jelent, valamint felkészít a rendszer második, mesterképzési ciklusába történő belépésre. Az alapszak képzési ideje három, legfeljebb négy év.

A rendelet melléklete a tanítóképzést a „pedagógusképzés” címen meghatározott képzési területhez, illetve az „óvodapedagógus, tanító” elnevezésủ alapszakos képzési ághoz sorolta. A nemzetiségi szakirányokkal társítható tanítóképzés „képzési kreditje" 240 kreditpont, amely változatlanul a négyéves, nyolc féléves képzési időszaknak felel meg. A HEFOP-pályázatok és az OPB koordináló tevékenysége által támogatott, megfeszített munka eredményeképpen a 2006/2007-es tanévtől megindulhatott a magyar felsőoktatás többciklusú, lineáris képzési rendszerében az alapképzési szakaszba sorolt tanítóképzés.

A pedagógusképzési alapszakokra mesterképzés építhető, a tanító szakra például a neveléstudományi mesterszak, a mesterszintủ végezettség pedig utat nyit a doktori képzésben való részvételre is (Kelemen, 2007). 


\section{Irodalom}

Bollókné, Panyik, I. \& Györgyné Hunyady (1995). A négyéves tanító szak programja. BTF.

Bollókné, Panyik, I. \& Györgyné Hunyady (2003). A tanítóképzés az integrált felsőoktatásban. Új Pedagógiai Szemle, 53(7-8). 4-16.

Dolmányos, I. (1968). A „Lex Apponyi” (Az 1907. évi iskolatörvények). Századok, 102(3-4). 484-535.

Felkai, L. (1979). Eötvös József közoktatásügyi tevékenysége. Akadémiai Kiadó.

Halász, F. (1902). Állami népoktatás. Atheneaum.

Halász, G. (2001). Az oktatási rendszer. Műszaki Kiadó.

Hunyady Györgyné (2012). Rendszerváltás a tanítóképzésben. In Donáth, P. (Ed.) Sorsforditó mozzanatok a magyarországi kisgyermekkori nevelóképzés, a Budapesti Tanitóképző Föiskola, az ELTE TOOK és épülete történetéből. Trezor Kiadó.

Kelemen, E. (2012). A Budapesti Tanítóképző Főiskolától az ELTE Tanító- és Óvóképző Főiskolai Karáig. In Donáth, P. (Ed) Sorsforditó mozzanatok a magyarországi kisgyermekkori nevelőképzés, a Budapesti Tanitóképző Föiskola, az ELTE TÓK és épülete történetéből (pp. 70-118), Trezor Kiadó.

Kelemen, E. (1993). A pedagógusképzés hazai történetének néhány kérdése. Pedagógusképzés, (1). 169-187.

Kelemen, E. (1994). A magyar oktatási törvénykezés története. Problématörténeti vázlat. In Kelemen, E. \& Setényi, J. Az oktatási törvénykezés változásai. Hazai és nemzetközi áttekintés. Bárczy István Könyvtár, 1. (pp. 11-97)

Kelemen, E. (1997). A népoktatás Magyarországon a dualizmus korában. In Somorjai, J. (Ed.) A népiskolák Magyarországon. Nemzetközi Iskolatörténeti Konferencia Tatabánya, 1996. aug. 26-27. (pp. 27-36). Tatabányai Múzeum, Tudományos Füzetek, 1.

Kelemen, E. (2001). A magyarországi népoktatás a dualizmus korában. In Balogh László (Ed.) Hagyomány és megújulás a magyar oktatásban (pp. 45-60). Neveléstörténeti füzetek, 19.

Kelemen, E. (2007). A tanító a történelem sodrában. Tanulmányok a magyar tanítóság 19-20. századi történetéből. Iskolakultúra-könyvek. 32.

Köte, S. (1975). Közoktatás és pedagógia az abszolutizmus és a dualizmus korában. (1948-1918). Tankönyvkiadó.

Mann, M. (1993). Kultúrpolitikusok a dualizmus korában. Országos Pedagógiai Könyvtár és Múzeum. 
Nagy, P. T. (1997). Hogyan kerüljük el a polgárosodást. Magyar oktatáspolitika 1867-1945.

Nagy, P. T. (2002). Hajszálcsövek és nyomáscsoportok. Oktatáspolitika a 19-20. századi Magyarországon. Oktatáskutató Intézet.

Podráczky, J. (2012). A budai képző mint a tanító- és óvóképzés országos szakmai egyeztető fórumának központja. A Tantervfejlesztő Bizottság tevékenysége. In Donáth, P. (Ed.) Sorsfordító mozzanatok a magyarországi kisgyermekkori nevelóképzés, a Budapesti Tanitóképző Főiskola, az ELTE TÓK és épülete történetéből (pp. 39-68.) Trezor Kiadó.

Sebestyén, Gy. (1896). Elemi iskolai tanitó- és tanitónőképzésünk.

Szakál, J. (1934): A magyar tanitóképzés története. Hollósy János.

\section{Turning points of the Hungarian elementary school teacher education}

The year 2019 also offers us three notable anniversaries from the history of Hungarian teacher education: 150 years ago, in 1869, the first - secondary - state teacher education institution was established on the basis of Eötvös' 1868 folk school law. 60 years ago, in 1959, academic - semi-tertiary - teacher education institutes were established to raise the level of education, and 25 years ago, in 1994, a system of qualification requirements was approved, which provided the professional basis for four-year college teacher education and paved the way for education offering 21st century perspectives for further development. The edited version of the lecture presents the historical changes and development of the 'state' teacher education in Hungary, arranged around the events of these three great eras as turning points.

Keywords: public teacher education, legal regulations, periods of teacher education 